\title{
Research investment disparities in England
}

DOI:

10.1016/S0140-6736(15)60919-9

Link to publication record in Manchester Research Explorer

\section{Citation for published version (APA):}

Yuille, M., Harrison, A., Williams, G., \& Verma, A. (2015). Research investment disparities in England. The Lancet, 385(9980), 1830-1830. https://doi.org/10.1016/S0140-6736(15)60919-9

\section{Published in:}

The Lancet

\section{Citing this paper}

Please note that where the full-text provided on Manchester Research Explorer is the Author Accepted Manuscript or Proof version this may differ from the final Published version. If citing, it is advised that you check and use the publisher's definitive version.

\section{General rights}

Copyright and moral rights for the publications made accessible in the Research Explorer are retained by the authors and/or other copyright owners and it is a condition of accessing publications that users recognise and abide by the legal requirements associated with these rights.

\section{Takedown policy}

If you believe that this document breaches copyright please refer to the University of Manchester's Takedown Procedures [http://man.ac.uk/04Y6Bo] or contact uml.scholarlycommunications@manchester.ac.uk providing relevant details, so we can investigate your claim.

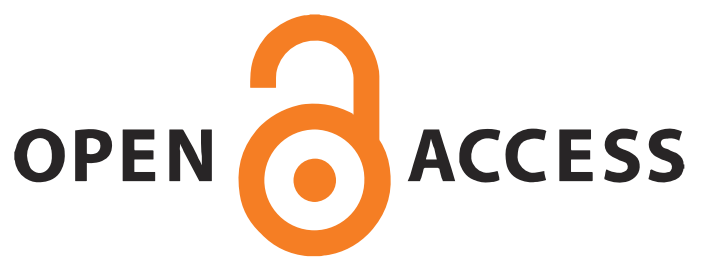




\section{Research investment disparities in England}

Are researchers in the so-called Northern Powerhouse (northwest and northeast England) getting a fair deal from government compared with those in the Golden Triangle (eastern and southeastern England, plus London)? For the first time, data from the Office of National Statistics (ONS) ${ }^{1}$ are enabling year-on-year comparisons by region for gross expenditure on research and development.

Between 2012, and 2013, the Northern Powerhouse's share of government investment rose from $3.51 \%$ to $3.73 \%$ (up by $0.22 \%$ ), while the Golden Triangle's share fell from $61 \cdot 33 \%$ to $61 \cdot 11 \%$ (down by $0.22 \%$ ). These changes ignore inflation (2-3\% per year in this period) and population differences.

To ascertain whether the Northern Powerhouse is getting a fair deal from the government, we defined fairness as being when the research investment per person reaches parity between regions. Between 2012, and 2013, investment per person rose by $£ 1.01$ in the Northern Powerhouse and by $£ 3.08$ in the Golden Triangle (table). ${ }^{2}$ After we corrected for $2 \%$ inflation, the increase in per capita investment was $£ 0.99$ for Northern Powerhouse and $£ 3.02$ for the Golden Triangle, which clearly shows increasing disparity. The Northern Powerhouse is not getting a fair deal: its deal is getting increasingly worse and other UK regions outside the Golden Triangle fare no better.

This gloomy outlook is not improved even when other sources of funding to the Northern Powerhouse are taken into account. Business investment has decreased by $0.65 \%$ and investment by the Higher Education Funding Council for England has been reduced by $0 \cdot 21 \%$ compared to an increase in the Golden Triangle of $0.37 \%$. Investment by charities has decreased across the board, but they represent only about $2 \%$ of total research investment.

The Golden Triangle is the only UK region characterised as a so-called innovation leader on the European Commission's Regional Innovation Scoreboard 2014. ${ }^{3}$ The Northern Powerhouse is an innovation follower, and the UK Government strategy has recognised the national importance of the north of England catching up to the south. ${ }^{4}$ If this strategy is to be successful, research investment needs to be reformed. Mazzucatto and colleagues ${ }^{5}$ have reported that regions

\begin{tabular}{|c|c|c|c|c|c|c|c|c|}
\hline & \multirow{2}{*}{$\begin{array}{l}\text { Population } \\
\text { (million } \\
\text { people) })^{2}\end{array}$} & \multicolumn{2}{|c|}{$\begin{array}{l}\text { Government research and } \\
\text { research councils }\end{array}$} & \multirow[t]{2}{*}{$\begin{array}{l}\text { Business } \\
\text { ( } £ \text { million) }\end{array}$} & \multirow{2}{*}{$\begin{array}{l}\text { Higher } \\
\text { education } \\
\text { ( } £ \text { million) }\end{array}$} & \multirow{2}{*}{$\begin{array}{l}\text { Private } \\
\text { non-profit } \\
\text { ( } £ \text { million) }\end{array}$} & \multirow[t]{2}{*}{$\begin{array}{l}\text { Total } \\
\text { ( } £ \text { million) }\end{array}$} & \multirow[t]{2}{*}{ Change } \\
\hline & & $\begin{array}{l}\text { Total spending } \\
\text { (£ million) }\end{array}$ & $\begin{array}{l}\text { Spending per } \\
\text { person }(£)\end{array}$ & & & & & \\
\hline \multicolumn{9}{|c|}{ Northern Powerhouse } \\
\hline 2012 & 9.6866 & 75 & $7 \cdot 74$ & 2057 & 813 & 63 & 3008 &.. \\
\hline 2013 & $9 \cdot 7138$ & 85 & 8.75 & 2093 & 850 & 57 & 3085 & $2 \cdot 56 \%$ \\
\hline \multicolumn{9}{|c|}{ Golden Triangle } \\
\hline 2012 & $22 \cdot 9404$ & 1310 & $57 \cdot 10$ & 9013 & 3427 & 443 & 14193 &.. \\
\hline 2013 & $23 \cdot 1633$ & 1394 & $60 \cdot 18$ & 9583 & 3678 & 429 & 15084 & $6 \cdot 28 \%$ \\
\hline \multicolumn{9}{|l|}{ UK } \\
\hline 2012 & $63 \cdot 7050$ & 2136 & $33 \cdot 53$ & 17144 & 7163 & 545 & 26988 &.. \\
\hline 2013 & $64 \cdot 1057$ & 2281 & $35 \cdot 58$ & 18448 & 7628 & 518 & 28875 & $6.99 \%$ \\
\hline $\begin{array}{l}\text { Data are } \\
\text { expendi } \\
\text { period. }\end{array}$ & $\begin{array}{l}\text { for National } \\
\text { arch and deve } \\
\text { werhouse=no }\end{array}$ & stics, National Rec & $\begin{array}{l}\text { ords of Scotland, } \\
\text { nural expenditure } \\
\text { eastern England. }\end{array}$ & and the North & southeaster & d eastern En & $\begin{array}{l}\text { h Agency. Gros } \\
\text { onal territory di } \\
\text { and, plus Lond }\end{array}$ & $\begin{array}{l}\text { domestic } \\
\text { uring a giver } \\
\text { n. }\end{array}$ \\
\hline
\end{tabular}

that are successful in innovation-led growth are those that have benefited from long-term mission-oriented research investment. This approach could help the UK to break out of the traditional feedback loops that reinforce this disparity.

We declare no competing interests.

Martin Yuille, Annie Harrison, Greg Williams, *Arpana Verma arpana.verma@manchester.ac.uk

University of Manchester, Manchester M13 9PT, UK

1 Office for National Statistics. Gross domestic expenditure on research and development, 2013. March 20, 2015. http://www.ons.gov. uk/ons/rel/rdit1/gross-domestic-expenditureon-research-and-development/2013/index. html (accessed April 19, 2015).

2 Office for National Statistics. Annual mid-year population estimates, 2013. June 26, 2014 http://www.ons.gov.uk/ons/dcp171778_367167. pdf (accessed April 19, 2015).

3 European Commission. Regional innovation scoreboard 2014. Brussels: European Commission, 2014.

4 Chancellor: "We need a Northern powerhouse" https://www.gov.uk/government/speeches/ chancellor-we-need-a-northern-powerhouse (accessed April 30, 2015).

5 Mazzucato M, Penna CCR. Mission-oriented finance for innovation. London: Policy Network and Rowman \& Littlefield International, 2015.

\section{End late registration of fact-of-death in England and Wales}

Agreement about the priorities for medical science ${ }^{1}$ should include commitment to end the late registration of fact-of-death in England and Wales.

In England and Wales (also Northern Ireland), if deaths are referred for inquest, fact-of-death is not registered with the Office for National Statistics (ONS) until the inquest verdict has determined cause of death. In England and Wales: 10000 deaths per year are not registered for at least six months.

With broad scientific support, including from Government Chief Scientists, National Statisticians and Chief Medical Officers, the Royal Statistical Society (RSS) has called for the dead in England and Wales to be 